\title{
Non-Price Tobacco Control Measures: Evidence from Turkey
}

\author{
Abdullah TiRGí* \\ Ankara Yildirim Beyazit University \\ Burcu ÜZER** \\ Ankara Yildirim Beyazit University \\ Furkan DALKILIÇ*** \\ Ankara Yildirim Beyazit University
}

\begin{abstract}
Turkey introduced the public-place and workplace smoking regulation in 2008, which was expanded in 2009, including hotels, restaurants, bars, and teahouses. We study the predictors of smoking status, smoking intensity, and exposure to environmental tobacco smoke (ETS) at home in Turkey. We then examine the relationship between the smoking bans and exposure to ETS at workplaces, home, and public places such as restaurants, teahouses, bars, and public transportation, including taxis using data from Turkey's Health Surveys about respondents' ETS exposure. Our multivariate regression analyses indicate that age, gender, marital status, employment status, income, and education have a statistically significant relationship with smoking status and smoking intensity. T-test results indicate that there has been an increase in exposure to ETS in public places between 2010 and 2012, which indicates weak enforcement of the law in the early years. Besides, exposure to ETS at workplaces have declined between 2010 and 2012. We also find that the public smoking ban did not lead to ETS displacement to private homes. We encourage policymakers to take more severe steps to enforce the law, especially in public places.
\end{abstract}

\section{Keywords}

Cigarette Consumption, Environmental Tobacco Smoking, Tobacco Control, Turkey

* Asst. Prof., Ankara Yildirim Beyazit University, Faculty of Political Sciences, Department of Public Finance, atirgil@ybu.edu.tr, ORCID: 0000-0002-4491-4459

** Master Student, Ankara Yildirim Beyazit University, Institute of Social Sciences, Department of Public Finance, 195209101@ybu.edu.tr, ORCID: 0000-0001-7259-9647

*** Master Student, Ankara Yildirim Beyazit University, Institute of Social Sciences, Department of Public Finance, furkanndalkilic@gmail.com, ORCID: 0000-0003-1909-6199 


\section{Fiyat Dıșı Tütün Kontrol Önlemleri Ve Çevresel Tütün Dumanına Maruz Kalma: Türkiye Örneği}

\section{Öz}

Türkiye, 2009 yılında kapsamı genişletilerek otel, restoran, bar ve kahvehaneleri kapsayan halka açık yerlerde ve işyerinde sigara içme yönetmeliğini 2008 yılında yürürlüğe koymuştur. Bu çalışmada Türkiye'de evde sigara içme durumu, sigara içme yoğunluğu ve çevresel tütün dumanına (ÇTD) maruz kalmanın faktörleri araştırılmıştır. Ardından, Türkiye Sağlık Araştırması anketine katılanların ÇTD’ye maruz kalma durumları hakkındaki Türkiye Sağlık Anketlerinden elde edilen veriler kullanılarak işyerlerinde, evlerde ve restoranlar, kahvehaneler, barlar ve toplu taşıma gibi halka açık yerlerde sigara içme yasakları ile ÇTD’ye maruz kalma arasındaki ilişki incelenmiştir. Çok değișkenli regresyon analizleri, yaș, cinsiyet, medeni durum, istihdam durumu, gelir ve eğitimin sigara içme durumu ve sigara içme yoğunluğu ile istatistiksel olarak anlamlı bir ilişki olduğunu işaret etmektedir. T-testi sonuçları, 2010 ile 2012 arasında halka açık yerlerde ÇTD’ye maruz kalma durumunda bir artış olduğunu göstermektedir. Bu durum ilk yıllarda yasanın uygulanma noktasında zayıf kaldığını belirtmektedir. Ayrıca, işyerlerinde ÇTD’ye maruz kalma 2010 ve 2012 yılları arasında azalmıştır. Ayrıca, kamuya açık sigara yasağının yer değiştirme etkisine yol açarak ÇTD’nin evlere taşınmasına yol açmadığı da saptanmıștır. Bulunan sonuçlar ışığında politika belirleyicileri, özellikle halka açık yerlerde, yasanın daha güçlü uygulanması için daha caydırıcı adımlar atmaya teşvik edilmektedir.

\section{Anahtar Kelimeler}

Sigara Tüketimi, Çevresel Tütün Dumanı, Tütün Kontrolü, Türkiye 


\section{Introduction}

Smoking is one of the most common harmful addictions. Nowadays, it is estimated that 1.3 billion people smoke globally, which indicates a prevalent behavior of tobacco use (WHO, 2020). According to the World Health Organization (WHO) data, about 80 percent of smokers are from low- and middle-income countries (WHO, 2020). Smoking threatens the health of not only smokers but also non-smokers and causes many fatal health problems. Regular smoking, being in smoking areas, and exposure to cigarette smoke cause respiratory system diseases, lung cancer -which is the most common cancer type, and cardiovascular diseases (Yanbaeva et al., 2007). There is also a risk of death in people who smoke for a long time and those exposed to heavy smoke (Jacobs et al., 1999; Wilson \& Thomson, 2002). Every year, 8 million people worldwide, including passive smokers, die from smoking (WHO, 2020).

In Turkey, as in other countries, tobacco use has become a significant public health problem in recent years. Struggling with smoking and cigarette consumption has been involved for many years in Turkey's agenda. The first legal regulation regarding the indoor smoking ban was in 1996. The first law on the prohibition of smoking in Turkey, Law No. 4207 "The Law on the Prevention of Harmful Effects of Tobacco Products," was published in 1996 and came into force (Official Journal, 1996). The purpose of this law is to take measures to protect individuals from the harm of tobacco and tobacco products, encouraging advertisements and incentive campaigns. However, the impact of this anti-tobacco regulation did not significantly affect cigarette consumption due in part to the weak enforcement of the law.

Turkey signed the World Health Organization's Framework Convention on Tobacco Control in 2004, and in 2006 the National Tobacco Control Program (NTCP) has been prepared. After these stages, Law No. 5727 was brought to the agenda. Law No. 5727 on Prevention and Control of Harms of Tobacco Products was adopted in 2008 by amending Law No. 4207, which prohibited smoking in all public buildings, public transportation, inside and outside schools, health, and social and cultural, sports and entertainment places.

With the adoption of Law No. 5727, the application area of Law No. 4207 has been considerably extended. In particular, the usage areas of tobacco products have been dramatically narrowed. As of 2009 , the smoking ban has been implemented in the hospitality sector, including hotels, restaurants, bars, and coffee shops (Warren et al., 2012). 
Environmental tobacco smoke (ETS) is another building block of this study, like smoking bans. ETS, or passive smoking, refers to involuntary exposure to tobacco smoke (WHO, 2000), mostly when non-smokers are exposed to cigarette smoke indoors. While adults are known to be exposed to cigarette smoke in closed areas such as homes, workplaces, cafes, restaurants, and bars, children are exposed to ETS at home and service vehicles. Exposure in personal vehicles while traveling is a potential source of exposure for both adults and children.

ETS is known to increase the risks of various health problems in non-smokers. For example, it has been found that non-smokers exposed to ETS may experience decreased lung function and increased frequency of respiratory symptoms (Spitzer et al., 1990; Leuenberger et al., 1994). Besides, exposure increases the risk of lung cancer and heart disease (Steenland, 1992; Hacksaw, Law, \& Wald, 1995; Glantz \& Parmley, 1995). Other studies have shown that exposure to ETS may increase the risk of cancer in organs other than the lung (Wells, 1991; Hirayama, 1992; Tredaniel et al., 1993). ETS can exacerbate allergy symptoms. It usually irritates the respiratory tract of asthma patients and exacerbates some asthma symptoms (Spitzer et al., 1990; Trédaniel et al., 1994). Pregnant individuals face low birth weight problems when exposed to ETS (Ahluwalia, Grummer-Strawn, \& Scanlon, 1997). Low birth weight babies are also less likely to survive, which increases infant mortality (Shapiro, McCormick, Starfield, Krischer, \& Bross, 1980; McCormick, Shapiro, and Starfield, 1984). Most non-smokers have complained of eye irritation, headache, cough, sore throat, and sneezing when exposed to ETS (Trédaniel et al., 1994; Coultas, 1998).

In this study, we first examine the predictors of smoking as measured by smoking status and smoking intensity between 2014 and 2016 after the two significant smoking ban policies. Then, we turn our focus to ETS and evaluate whether public and workplace smoking bans had any effects on ETS between 2010 and 2012. We analyze the extent of ETS exposure at home, workplace, and public areas. We also investigate the extent of ETS exposure at restaurants, teahouses, bars, and public transportation, including taxis. Finally, we look at what factors determine the ETS at home.

The remainder of our study is organized as follows. In the next section, the related literature is reviewed; in the third section, the data is explained. In the fourth section, the method is described; in the fifth section, the results are interpreted. Finally, we discuss our findings.

\section{Literature Review}

Cigarette consumption is quite popular in Turkey, and according to results of the Global Adult Tobacco survey held in 2012 by the cooperation of the WHO and the Turkish Ministry of Health, a total of 27.1\% (14.8 million) of adults 
were actively smoking in Turkey, and the prevalence was $41.5 \%$ among men and $13.1 \%$ among women. WHO (2010) also reports that tobacco use is a risk factor for six of the eight leading causes of death globally and caused 5.4 million deaths in 2005, which is predicted to rise to 8.3 million by 2030 .

There are various studies in the literature concerning both tobacco consumption and anti-tobacco policies. Evidence suggests that age, education, and gender are significant determinants of smoking behavior. Singh and Ladusingh (2014) find that tobacco consumption is higher among males, less educated individuals, and people with lower income levels in India. In addition to that, the amount of tobacco consumption increases with age among females. Similarly, Khanal, Adhikari, and Karki (2013) indicate that older males with less education are likely to consume more tobacco products in Nepal. An alternative study by Aristei and Pieroni (2008) in Italy shows that individuals with a higher level of education and income are less likely to consume tobacco. Hosseinpoor, Parker, d'Espaignet, and Chatterji (2011), concerning lowand middle-income countries, indicate that, depending on the income level of the nations, determinants such as age and wealth show different effects on smoking behavior. However, less educated individuals are more likely to smoke regardless of their gender or income level.

Research points out that males and females show significantly different patterns of tobacco consumption. Gender differences in tobacco consumption have been paid great attention in the literature. For example, Chaloupka and Pacula (1999) study the responsiveness of youth to the anti-tobacco policies based on gender and race differences. Young men are found to be much more responsive to changes in cigarette prices compared to young women. Similar to this research, Lan and Chaloupka (2002) examine the differential effects of cigarette prices on the intensity of youth cigarette smoking. They argue that cigarette prices are a valuable tool to discourage youth smoking.

Some other studies focus on potential incentive factors to start smoking. Kelishadi et al. (2007) study possible motivating factors to smoke, especially for youth in Iran. Their findings show that significant motivations to smoke are seeking attention from friends, lack of family attention, and poverty. Anti-tobacco policies and their success are also critical topics in the literature. There is much research all around the globe to provide evidence on the matter. Levy, Chaloupka, and Gitchell (2004) review the literature and find that a tax increase on tobacco products and the implication of comprehensive clean air laws are the most successful policies in reducing smoking rates. Also, Keeler, Hu, Barnett, and Manning (1993) research the effects of a tax increase on smoking behavior and find that cigarette consumption would be reduced remarkably by 10 to 12 percent in the long run.

Moreover, Anger, Kvasnicka, and Siedler (2010) study the impact of the state-level public smoking ban in Germany. Their findings indicate that the 
implied public smoking ban does not change the overall smoking behavior. However, specific groups that spend more time in public places adjust their smoking behavior due to the constraints of the public smoking ban. Adda and Cornaglia (2006) research the effects of taxation on smoking behavior. They find that smokers adjust both their cigarette consumption and the amount of nicotine they extract by smoking more intensely. Tauras (2006) indicates that more restrictive smoke-free air laws decrease the average cigarette use by adult smokers but have little impact on smoking. Furthermore, Jones, Laporte, Rice, and Zucchelli (2015) investigate the effects of public smoking bans on active smoking in England and Scotland and argue that public smoking bans had a negligible impact on the number of smokers and the total level of consumption in the short run.

Another strand of literature focuses on workplace smoking bans. For example, Bardsley and Olekalns (1999) study the effects of anti-tobacco policies in Australia. They find that workplace smoking bans and the health warnings on cigarette packages have reduced tobacco consumption. Other studies are looking at the impact of workplace smoking bans, and all find that the bans significantly reduce overall cigarette consumption (Borland et al., 1990; Fichtenberg \& Glantz, 2002; Fong et al., 2006).

Another critical strand of research focuses on environmental tobacco smoke. Öberg (2011) conducts his research concerning the worldwide burden caused by environmental tobacco smoke. Their findings indicate that $40 \%$ of children, more than $30 \%$ of male and female non-smokers, were exposed to environmental tobacco smoke, related to the diseases that caused 603,000 estimated deaths in 2004. Rachiotis et al. (2010) show that teenagers older than 15 are significantly subject to higher exposure to environmental tobacco smoke. Overall, males were less likely to suffer from it when compared to females.

Furthermore, Adda and Cornaglia (2010) find that a tax-increasing policy reduces the overall exposure to environmental tobacco smoke. However, they also indicate that public smoking ban policies might have a displacing effect on smokers, leading to environmental tobacco smoke exposure at home. Also, Carpenter, Postolek, and Warman (2011) argue that public-place smoking bans in Canada significantly reduce environmental tobacco exposure in public places, especially in bars and restaurants. Furthermore, they find that public-place smoking bans have no statistically significant effects on lowering population smoking participation or smoking intensity.

Similar to our study, there are also various studies concerning tobacco consumption in Turkey. Eraslan, Demirkıran, and Duran (2019) find that gender and educational attainment are significant predictors of smoking behavior. Kilic and Öztürk (2014) report that men and women in Turkey have different motives to consume tobacco. Education, cigarette taxation, and advertisement 
bans have different influences on tobacco consumption depending on gender. Köse (2019) approaches the problem differently and tries to understand gender differences in smoking quitting attempts. He points out that women in Turkey are $20 \%$ less likely to attempt quitting smoking than men. Argüder, Karalezli, and Hasanoğlu (2019) research the factors that influence smoking initiation in Turkey. Their results imply that curiosity and having friends with smoking habits were the main reasons to start smoking for most cases and the psychological, social, and surrounding factors. Another critical study argues that weight control, boredom reduction, and social gains are associated with smoking's positive expectations. In contrast, health costs, addiction, and social costs are associated with negative smoking expectations (Yazıcl, Camadan, \& Kahveci, 2017).

Warren et al. (2012) study the effects of anti-tobacco policies in Turkey and show that a $10.7 \%$ decrease has been observed in cigarette sales after two significant anti-tobacco policies, including the public smoke-free law and a $20 \%$ tax increase. On the contrary, a recent study by Ylld lz (2020) argues that tobacco control policies positively affect cigarette consumption. The main reason behind this contradiction should be caused by the fact that Warren et al. (2012) use cigarette sales data in their study and include the effect of tax imposed on tobacco products. However, Ylldız (2020) studies the determinants of cigarette consumption and suggests that tobacco control policies positively affect cigarette consumption. Besides, both studies agree on the declining effects of the price increase. Moreover, these studies utilize different econometric methods and different periods to study smoking, which can be another reason for the contradiction.

After reviewing the literature from various researches and locations, it is agreed that age, gender, marital status, education level, household income, urbanicity, and household size are significant determinants of tobacco consumption. Almost all of the studies show that the prevalence of smoking is higher among males than females. Although the determinants and reasons for smoking behavior are similar in all studies, different anti-tobacco policies show different results worldwide. In contrast to the review, a gap in the literature is noticed concerning public smoking ban implications on environmental tobacco smoke exposure. We aim to fill that gap with our study.

\section{Data}

In this paper, we study environmental tobacco smoking after a primary anti-tobacco policy put into effect in 2009 in Turkey. To do our analyses, we use individual-level data obtained from Turkey's Health Surveys (THS) conducted by the Turkish Statistical Institute (TurkStat). Our analyses cover the period 2010 through 2016. The datasets are nationally representative datasets, excluding those living in long-term care institutions. TurkStat has been implementing these surveys every two years since 2008. We cannot use the 
2008 survey because it does not include questions about tobacco smoking or environmental tobacco smoking.

The datasets include a wide range of topics such as smoking status and smoking intensity. The surveys ask several essential questions concerning ETS, including whether one is exposed to ETS at home, public places, and workplaces. The surveys also asked direct questions to the individuals whether they were exposed to smoke after the smoking ban went into implementation in 2009, such as exposure at restaurants, Turkish teahouses, bars, and public transportation, including taxis.

The THSs also ask many questions, which allow us to control a broad range of individual characteristics in our regression analyses. The surveys include information on respondents' age, gender, marital status (single or married), educational attainment (illiterate, primary school, middle school, high school, and university or more), household income, urbanicity, household size, and presence of kids at home aged between 0 and 14 years old. The surveys also include statistical area dummies for 26 regions of Turkey and survey year dummies.

\section{Methods}

In this study, we investigate several outcome variables by implementing multivariate regression analyses. We first start with each respondent's current smoking status. For this analysis, we utilize information from recent datasets (2014 and 2016) because the question asked in 2014 and 2016 do not match with the question asked in previous years. The survey question asks, "Do you smoke?" Responses to the current smoking question are Yes, every day; Yes, sometimes; Never; and quit. We construct a discrete variable based on these responses, taking the value of 1 if the person states every day and sometimes and 0 otherwise.

Then, we examine each respondent's smoking intensity for the same years. As before, the question asked in 2014 and 2016 does not match the question in previous years, which prohibits using 2010 and 2012 Health Surveys. The survey asks, "On average, how many cigarettes do you smoke daily?" Based on this information, we create a natural log of this variable conditional on the respondent smokes every day or sometimes.

We then examine the predictors of the ETS at home environment, covering the period 2010 and 2012 since we are unable to match the recent years.

We employ a linear probability model as in Eq.(1). Angrist and Pischke (2008) argued why we could choose a linear model over a nonlinear model when the dependent variable is discrete (Angrist \& Pischke, 2008). They argue that when it comes to marginal effects choosing a linear model over a nonlinear model matters little (Angrist \& Pischke, 2008). We estimate an economic 
model where we incorporate individual-level characteristics into our regression analyses, including age and its square, gender, marital status, educational levels, log income, urban, household size, and presence of kids. We also include 26 statistical area dummies to control regional variations and survey year fixed effects in our analysis.

Our estimation equation is as follows:

$$
Y_{i t}=\partial_{0}+\varphi X_{i t}+\epsilon_{i t},(1)
$$

where $i$ and $t$ denote individuals and time, respectively, $Y_{i t}$ can be smoking status, smoking intensity, and ETS exposure at home. $X_{i t}$ denotes individual characteristics, including age, gender, marital status, educational attainment, income, household size, presence of kids at home, employment status, 26 statistical area dummies, and survey years. $\epsilon_{i t}$ is the error term. $\varphi$ is a vector of parameters to be estimated.

Furthermore, we wanted to evaluate the relationship between the public-place smoking ban and ETS. To do this, we take advantage of a wide range of questions asked in the survey. Here, we implement a two-sample t-test, which is used to test the hypothesis that the means of the variables are equal. Concerning ETS, the survey asks the question, "How frequently are you exposed to ETS?" which is asked for the respondent's home; public places such as teahouses, movie theaters, restaurants, and shopping centers; and workplaces. The responses to these questions are Never, less than one hour a day, between 1-5 hours a day, and more than 5 hours a day. Based on this information, we construct a binary variable, which is 1 if the person is exposed to ETS irrespective of time and 0 otherwise. If respondents do not work in a closed environment, then we code them as 0 .

Besides this, we have detailed questions asking about ETS after the anti-tobacco law went into effect in 2009. The question reads, "whether you are exposed to tobacco consumption at the listed places after the implementation of the smoking ban in July 2009?" These places include restaurants, teahouses, bars, and public transportation, including taxis. The analysis uses the datasets from 2010 and 2012 surveys as these questions were not asked in recent surveys (2014 and 2016). Therefore, we can only evaluate the early effects of the anti-smoking law on ETS.

In the surveys, the household income variable is in brackets. Therefore, we take the midpoints of each income bracket and the minimum point of the last income bracket and take the natural log of these incomes. For the presence of kids, we create a binary variable taking the value 1 if there is anyone aged between $0-14$ at home and 0 otherwise. We did this because we wanted to see if ETS declines with the presence of kids at home. 


\section{Results}

Table 1 presents the determinants of smoking status (column 1) and smoking intensity (column 2) after the anti-tobacco policy law went into effect in 2009 in Turkey. Age variable shows an inverse-U relationship with smoking participation such that as age increases, smoking participation increases; however, at some point, this positive relationship turns to a negative correlation between age and smoking participation. Smoking participation for females is much less compared to males by 22 percentage points. Besides, married individuals report less smoking participation in comparison to single individuals. With more education, illiterate being the reference category, smoking participation increases except for university or more graduates who are less likely to smoke than the illiterate respondents. For these variables, results for smoking intensity provide qualitatively similar estimations.

Some impressive results emerge from Table 1 . While there is a positive relationship between having children and smoking participation, the relationship between having children and smoking intensity is negative. Also, employed individuals are more likely to participate in smoking, and they smoke more in quantity. Finally, the trend variable (year dummy) does not show any statistically significant decline in either smoking status or smoking intensity, which may indicate a less impact of the anti-smoking policy after seven years.

Table 1. Determinants of smoking as measured by smoking status and smoking intensity (2014-2016)

\begin{tabular}{|c|c|c|}
\hline & $\begin{array}{l}\text { Smoking status } \\
\text { (1) }\end{array}$ & $\begin{array}{c}\text { Smoking intensity (Log of cigarettes) } \\
\text { (2) }\end{array}$ \\
\hline Age & $\begin{array}{l}0.022^{* * *} \\
(0.001)\end{array}$ & $\begin{array}{l}0.034^{* * *} \\
(0.003)\end{array}$ \\
\hline Age squared & $\begin{array}{l}-0.000^{* * *} \\
(0.000)\end{array}$ & $\begin{array}{c}-0.000^{* * *} \\
(0.000)\end{array}$ \\
\hline Female & $\begin{array}{l}-0.220^{* * *} \\
(0.005)\end{array}$ & $\begin{array}{l}-0.479^{* * *} \\
(0.019)\end{array}$ \\
\hline Married & $\begin{array}{l}-0.049^{* * *} \\
(0.006)\end{array}$ & $\begin{array}{l}-0.122^{* * *} \\
(0.022)\end{array}$ \\
\hline Illiterate & Ref. & Ref. \\
\hline Primary & $\begin{array}{l}0.014^{* *} \\
(0.007)\end{array}$ & $\begin{array}{c}0.017 \\
(0.034)\end{array}$ \\
\hline Middle school & $\begin{array}{l}0.052^{* * *} \\
(0.010)\end{array}$ & $\begin{array}{c}0.038 \\
(0.038)\end{array}$ \\
\hline High school & $\begin{array}{l}0.067^{* * *} \\
(0.009)\end{array}$ & $\begin{array}{c}0.002 \\
(0.037)\end{array}$ \\
\hline University or more & $\begin{array}{l}-0.035^{* * *} \\
(0.010)\end{array}$ & $\begin{array}{l}-0.094^{* *} \\
(0.041)\end{array}$ \\
\hline Log income & $\begin{array}{c}-0.015^{* * *} \\
(0.004)\end{array}$ & $\begin{array}{c}-0.037^{* * *} \\
(0.014)\end{array}$ \\
\hline
\end{tabular}




\begin{tabular}{|c|c|c|}
\hline Household size & $\begin{array}{c}-0.011^{* * *} \\
(0.002)\end{array}$ & $\begin{array}{c}0.009 \\
(0.006)\end{array}$ \\
\hline Presence of kids & $\begin{array}{l}0.041^{* * *} \\
(0.007)\end{array}$ & $\begin{array}{c}-0.041^{* *} \\
(0.021)\end{array}$ \\
\hline Employed & $\begin{array}{l}0.095^{\text {**** }} \\
(0.006)\end{array}$ & $\begin{array}{c}0.050^{\text {****}} \\
(0.018)\end{array}$ \\
\hline \multicolumn{3}{|l|}{ Years } \\
\hline 2014 & Ref. & Ref. \\
\hline 2016 & $\begin{array}{l}-0.008 \\
(0.005)\end{array}$ & $\begin{array}{c}-0.023 \\
(0.016)\end{array}$ \\
\hline Constant & $\begin{array}{l}0.107^{* * *} \\
(0.037)\end{array}$ & $\begin{array}{l}2.111^{* * *} \\
(0.129)\end{array}$ \\
\hline R-squared & 0.140 & 0.114 \\
\hline $\mathbf{N}$ & 36371 & 10047 \\
\hline
\end{tabular}

Notes: Sample in all models includes adults aged 15+ in the Turkey Health Surveys 20142016. The dependent variable in column 1 is a discrete variable equal to 1 if the person reports being a current smoker. The dependent variable in column 2 is the natural log of the number of cigarettes smoked every day on average. Individual demographic controls are age and its square, a female dummy, marital status (single or married), four education dummies, log income, household size, presence of kids at home, and employed. We also control for survey year and 26 statistical area dummies. Robust standard errors in parentheses are clustered at the household level. ${ }^{*} p<.1,{ }^{* *} p<.05,{ }^{* * *} p<.01$.

Table 2 reports the means for ETS exposure at various public venues and workplaces by years after the smoking ban put into effect in 2009. Panel A of Table 2 shows that being exposed to ETS at home significantly declined from 2010 to 2012. However, ETS at public places such as teahouses, movie theaters, restaurants, or shopping malls significantly increased. In the meantime, ETS at workplaces declined significantly by $55 \%$, which indicates the workplace ban was effective in the early years of the ban. We then investigate ETS at different public places, including restaurants, teahouses, bars, and public transportation, including taxis. What stands out from the estimations is that in all public places, ETS seems to be increasing from 2010 to 2012, meaning that the enforcement of the anti-smoking law has been weak concerning public places in the early years of the ban.

Table 2. Public-place and workplace smoking ban and environmental tobacco smoking (ETS) (2010-2012)

\begin{tabular}{lccc}
\hline & $\mathbf{2 0 1 0}$ & $\mathbf{2 0 1 2}$ & Total \\
\hline Panel A & & & \\
\hline \multirow{2}{*}{ Exposed at home } & 0.250 & 0.220 & $0.230^{* * *}$ \\
& {$[0.433]$} & {$[0.414]$} & {$[0.421]$} \\
\hline \multirow{2}{*}{ Exposed at public places } & 0.033 & 0.040 & $0.037^{* * *}$ \\
\hline
\end{tabular}




\begin{tabular}{lccc}
\hline Exposed at workplace & 0.056 & 0.025 & $0.030^{* * *}$ \\
\hline Panel B & {$[0.229]$} & {$[0.155]$} & {$[0.169]$} \\
\hline \multirow{2}{*}{ Exposed at restaurants } & & & \\
\hline \multirow{2}{*}{ Exposed at teahouses } & 0.103 & 0.130 & $0.121^{* * *}$ \\
\hline \multirow{2}{*}{ Exposed at bars } & $0.103]$ & {$[0.336]$} & {$[0.326]$} \\
\hline Exposed at public transportation & {$[0.309]$} & 0.141 & $0.126^{* * *}$ \\
including taxis & 0.064 & {$[0.348]$} & {$[0.332]$} \\
\hline \multirow{2}{*}{$N$} & {$[0.244]$} & 0.090 & $0.081^{* * *}$ \\
\hline
\end{tabular}

Notes: mean coefficients; sd in brackets. ${ }^{*} \mathrm{p}<0.05,{ }^{* *} \mathrm{p}<0.01,{ }^{* * *} \mathrm{p}<0.001$. Analysis covers the period 2010 through 2012. Significance values report the difference for the variables between 2010 and 2012.

Finally, we estimate the predictors of ETS at home in Table 3. Results indicate that married individuals are less likely to be exposed to ETS at home. Those who live in urban areas state that they are more likely to be exposed to ETS at home, which may indicate that they do not have available spots at home to smoke. Another significant result is that having kids at home reduces the probability of second-hand smoking. Year dummies indicate that smoking bans in public places and workplaces did not lead to more ETS exposure at home during the studied period. Also, educated people are less likely to be exposed to ETS at home, especially university graduates or more. 
Table 3. Associated factors of ETS exposure at home (2010-2012)

\begin{tabular}{|c|c|c|c|}
\hline & All & Urban & Rural \\
\hline Age & $\begin{array}{l}0.005^{* * *} \\
(0.001)\end{array}$ & $\begin{array}{l}0.007^{* * *} \\
(0.001)\end{array}$ & $\begin{array}{c}0.001 \\
(0.001)\end{array}$ \\
\hline Age squared & $\begin{array}{c}-0.000^{* * *} \\
(0.000)\end{array}$ & $\begin{array}{c}-0.000^{* * *} \\
(0.000)\end{array}$ & $\begin{array}{c}-0.000^{* * *} \\
(0.000)\end{array}$ \\
\hline Female & $\begin{array}{c}0.000 \\
(0.004)\end{array}$ & $\begin{array}{c}-0.003 \\
(0.004)\end{array}$ & $\begin{array}{c}0.011 \\
(0.007)\end{array}$ \\
\hline Married & $\begin{array}{c}-0.020^{* * *} \\
(0.006)\end{array}$ & $\begin{array}{c}-0.033^{* * *} \\
(0.008) \\
\end{array}$ & $\begin{array}{c}0.014 \\
(0.011)\end{array}$ \\
\hline Illiterate & Ref. & Ref. & Ref. \\
\hline Primary & $\begin{array}{c}0.001 \\
(0.007)\end{array}$ & $\begin{array}{c}0.002 \\
(0.009)\end{array}$ & $\begin{array}{c}-0.001 \\
(0.011)\end{array}$ \\
\hline Middle school & $\begin{array}{c}-0.007 \\
(0.009)\end{array}$ & $\begin{array}{c}-0.011 \\
(0.011)\end{array}$ & $\begin{array}{c}0.004 \\
(0.018)\end{array}$ \\
\hline High school & $\begin{array}{c}-0.025^{* * *} \\
(0.009)\end{array}$ & $\begin{array}{c}-0.031^{* * *} \\
(0.011)\end{array}$ & $\begin{array}{c}0.004 \\
(0.020)\end{array}$ \\
\hline University or more & $\begin{array}{c}-0.086^{* * *} \\
(0.010)\end{array}$ & $\begin{array}{c}-0.090^{* * *} \\
(0.012) \\
\end{array}$ & $\begin{array}{c}-0.065^{\text {*** }} \\
(0.025)\end{array}$ \\
\hline Log income & $\begin{array}{c}-0.019^{* * *} \\
(0.005)\end{array}$ & $\begin{array}{c}-0.028^{* * *} \\
(0.007)\end{array}$ & $\begin{array}{c}-0.007 \\
(0.009)\end{array}$ \\
\hline Urban & $\begin{array}{l}0.033^{* * *} \\
(0.008)\end{array}$ & - & - \\
\hline Household size & $\begin{array}{l}0.008^{* * *} \\
(0.003)\end{array}$ & $\begin{array}{c}0.004 \\
(0.003)\end{array}$ & $\begin{array}{c}0.012^{* * *} \\
(0.005)\end{array}$ \\
\hline Presence of kids & $\begin{array}{c}-0.023^{* * *} \\
(0.008)\end{array}$ & $\begin{array}{c}-0.026^{* * *} \\
(0.009)\end{array}$ & $\begin{array}{c}-0.014 \\
(0.017)\end{array}$ \\
\hline \multicolumn{4}{|l|}{ Years } \\
\hline 2010 & Ref. & Ref. & Ref. \\
\hline 2012 & $\begin{array}{c}-0.023^{* * *} \\
(0.006)\end{array}$ & $\begin{array}{c}-0.025^{\text {*** }} \\
(0.008)\end{array}$ & $\begin{array}{c}-0.015 \\
(0.012)\end{array}$ \\
\hline Constant & $\begin{array}{l}0.376^{* * *} \\
(0.043)\end{array}$ & $\begin{array}{l}0.470^{* * *} \\
(0.058)\end{array}$ & $\begin{array}{l}0.296^{* * *} \\
(0.070)\end{array}$ \\
\hline R-squared & 0.033 & 0.031 & 0.047 \\
\hline $\mathbf{N}$ & 42502 & 30932 & 11570 \\
\hline \multicolumn{4}{|c|}{$\begin{array}{l}\text { Notes: Sample includes adults aged } 15+\text { in the Turkey Health Surveys } 2010-2012 \text {. The depen- } \\
\text { dent variable in all models is a discrete variable equal to } 1 \text { if the person reports being exposed } \\
\text { to smoke at home, } 0 \text { otherwise. Individual demographic controls are age and its square, a } \\
\text { female dummy, marital status (single or married), four education dummies, log income, urba- } \\
\text { nicity, household size, and presence of kids aged } 0-14 \text { at home. We also control for year and } \\
26 \text { statistical area dummies. Robust standard errors in parentheses are clustered at the hou- } \\
\text { sehold level. }{ }^{*} \mathrm{p}<.1,{ }^{* *} \mathrm{p}<.05,{ }^{* *} \mathrm{p}<.01 \text {. }\end{array}$} \\
\hline
\end{tabular}




\section{Discussion}

It is scientifically proven that tobacco consumption is a major cause of significant health problems such as heart diseases, different types of cancers, and lung diseases (WHO, 2010). Therefore, anti-tobacco policies are critical phenomena for policymakers to reduce tobacco consumption. However, the success of an anti-tobacco policy is as remarkable as the implications themselves.

Turkey implemented a significant public and workplace smoking ban in 2008, and it was extended to include the hospitality sector in 2009. Our study has three parts. In the first part, we examine the determinants of smoking status and smoking intensity after implementing the two significant anti-tobacco policies. Then, the second part investigates the effectiveness of the two significant smoking bans on ETS at different venues such as homes, public places, workplaces, restaurants, teahouses, bars, and public transportation, including taxis. Finally, we investigate the determinants of ETS exposure at home.

Our findings indicate that age, gender, marital status, employment status, and income are significant predictors of cigarette consumption measured as smoking status and smoking intensity, which is consistent with the literature (Kelishadi et al., 2007; Aristei \& Pieroni, 2008; Hosseinpoor et al.,2011; Khanal, Adhikari, \& Karki, 2013; Singh \& Ladusingh, 2014; Eraslan, Demirkıran, \& Duran, 2019;). Age shows an inverse-U relationship with smoking status and smoking intensity, which may be an indication of older people concerning more about their health. Our results show that college or more educated people are less likely to be smokers and more likely to consume fewer cigarettes, which can be explained by the fact that they may be more aware of the health problems that smoking causes.

Although Turkey introduced a workplace smoking ban, our results indicate that the probability of smoking and smoking intensity is higher for employed individuals, which does not necessarily mean that the workplace ban is useless. Concerning the workplace ban concerning ETS, our findings show a significant decline by 55\% between 2010 and 2012, which indicates the workplace ban has been active in the early years of the ban and is consistent with the literature (Borland et al., 1990; Bardsley \& Olekalns, 1999; Fichtenberg \& Glantz, 2002; Fong et al., 2006).

We find that the smoking ban in public places and workplaces did not lead to more ETS exposure at home during the studied period in Turkey, which is inconsistent with the results of Adda and Cornaglia (2010). On the contrary, our findings show that exposure to ETS at home significantly declined from 2010 to 2012, which may indicate fewer ETS by children. However, our results also show that the ETS exposure in all public places has increased, which means that the public smoking ban has been weak concerning public places in the early years of the smoking ban. 
Our study has some limitations. First, we do not have information on smoking participation, smoking intensity, and smoking in public places and workplaces to use in our analyses before the anti-tobacco policy went into effect in 2009 in Turkey. Therefore, we cannot implement before and after analyses. Another limitation is that surveys do not ask the same question over the years for outcome variables. Therefore, we had to use more recent data to understand the factors of smoking participation and smoking intensity. For the ETS analyses, we had to investigate the early impact of the anti-tobacco policies.

Notwithstanding limitations, the findings of the study are of great importance to policymakers. Although the early period for which the public place and workplace smoking bans did not cause more ETS exposure at home and workplace, ETS interestingly occurred at restaurants, teahouses, bars, and public transportation, including taxis. Therefore, we suggest that to reduce exposure to ETS in public places, law enforcement and criminal sanctions can be increased in places where smoking is prohibited, or there may be alternative rooms that smokers can use.

\section{References}

Adda, J., \& Cornaglia, F. (2006). Taxes, cigarette consumption, and smoking intensity. American Economic Review, 96(4), 1013-1028.

Adda, J., \& Cornaglia, F. (2010). The effect of bans and taxes on passive smoking. American Economic Journal: Applied Economics, 2(1), 1-32.

Ahluwalia, I. B., Grummer-Strawn, L., \& Scanlon, K. S. (1997). Exposure to environmental tobacco smoke and birth outcome: increased effects on pregnant women aged 30 years or older. American journal of epidemiology, 146(1), 42-47. https://doi. org/10.1093/oxfordjournals.aje.a009190

Anger, S., Kvasnicka, M., \& Siedler, T. (2011). One last puff? Public smoking bans and smoking behavior. Journal of health economics, 30(3), 591-601.

Angrist, J. D., \& Pischke, J. S. (2008). Mostly harmless econometrics: An empiricist's companion. Princeton university press.

Argüder, E., Pempeci, S., Karalezli, A., \& Hasanoğlu, H. C. (2019). The factors that influence smoking initiation. Addicta: The Turkish Journal on Addictions, 6(4), 116129.http://dx.doi.org/10.5152/addicta.2020.19099

Aristei, D., \& Pieroni, L. (2008). A double-hurdle approach to modelling tobacco consumption in Italy. Applied economics, 40(19), 2463-2476. https://doi. org/10.1080/00036840600970229

Bardsley, P., \& Olekalns, N. (1999). Cigarette and tobacco consumption: Have anti-smoking policies made a difference?. Economic Record, 75(3), 225-240.

Bilir, N., Çakır, B., Dağlı, E., Ergüder, T., \& Önder, Z. (2009). Tobacco control Turkey. Copenhagen: World Health Organization. 
Blas, E., \& Kurup, A. S. (Eds.). (2010). Equity, social determinants and public health programmes. World Health Organization.

Borland, R., Chapman, S., Owen, N., \& Hill, D. (1990). Effects of workplace smoking bans on cigarette consumption. American Journal of Public Health, 80(2), 178-180.

Carpenter, C., Postolek, S., \& Warman, C. (2011). Public-place smoking laws and exposure to environmental tobacco smoke (ETS). American Economic Journal: Economic Policy, 3(3), 35-61.

Chaloupka, F. J., \& Pacula, R. L. (1999). Sex and race differences in young people's responsiveness to price and tobacco control policies. Tobacco Control, 8(4), 373377. DOI: $10.1002 /$ hec.3009

Chilmonczyk, B. A., Salmun, L. M., Megathlin, K. N., Neveux, L. M., Palomaki, G. E., Knight, G. J., Pulkkinen, A. J., \& Haddow, J. E. (1993). Association between exposure to environmental tobacco smoke and exacerbations of asthma in children. The New England journal of medicine, 328(23), 1665-1669. https://doi.org/10.1056/ NEJM199306103282303

Coultas D. B. (1998). Health effects of passive smoking. 8. Passive smoking and risk of adult asthma and COPD: an update. Thorax, 53(5), 381-387. https://doi. org/10.1136/thx.53.5.381

Fichtenberg, C. M., \& Glantz, S. A. (2002). Effect of smoke-free workplaces on smoking behaviour: systematic review. Bmj, 325(7357), 188.

Fong, G. T., Hyland, A., Borland, R., Hammond, D., Hastings, G., McNeill, A., ... \& Howell, F. (2006). Reductions in tobacco smoke pollution and increases in support for smoke-free public places following the implementation of comprehensive smoke-free workplace legislation in the Republic of Ireland: findings from the ITC Ireland/U.K. Survey. Tobacco control, 15(suppl 3), iii51-iii58.

Glantz, S. A., \& Parmley, W. W. (1995). Passive smoking and heart disease. Mechanisms and risk. JAMA, 273(13), 1047-1053.

Hackshaw, A. K., Law, M. R., \& Wald, N. J. (1997). The accumulated evidence on lung cancer and environmental tobacco smoke. BMJ (Clinical research ed.), 315(7114), 980-988. https://doi.org/10.1136/bmj.315.7114.980

Hirayama, T. Lung cancer and other diseases related to passive smoking: a large-scale cohort study. In: Gupta, P.C. et al., ed. Control of tobacco-related cancers and other diseases. Bombay, Oxford University Press, 1992.

Hosseinpoor, A. R., Parker, L. A., d'Espaignet, E. T., \& Chatterji, S. (2011). Social determinants of smoking in low-and middle-income countries: results from the World Health Survey. PloS one, 6(5).

Jacobs, D. R., Adachi, H., Mulder, I., Kromhout, D., Menotti, A., Nissinen, A., \& Blackburn, H. (1999). Cigarette smoking and mortality risk: twenty-five-year follow-up of the seven countries study. Archives of internal medicine, 159(7), 733-740. 
Jones, A. M., Laporte, A., Rice, N., \& Zucchelli, E. (2015). Do public smoking bans have an impact on active smoking? Evidence from the U.K. Health economics, 24(2), 175-192.

Keeler, T. E., Hu, T. W., Barnett, P. G., \& Manning, W. G. (1993). Taxation, regulation, and addiction: a demand function for cigarettes based on time-series evidence. Journal of health economics, 12(1), 1-18.

Kelishadi, R., Reza Mokhtari, M., Tavasoli, A. A., Khosravi, A., Ahangar-Nazari, I., Sabet, B., ... \& Amini, A. (2007). Determinants of tobacco use among youths in Isfahan, Iran. International journal of public health, 52(3), 173-179.

Khanal, V., Adhikari, M., \& Karki, S. (2013). Social determinants of tobacco consumption among Nepalese men: findings from Nepal Demographic and Health Survey 2011. Harm reduction journal, 10(1), 40.

Kilic, D., \& Ozturk, S. (2014). Gender differences in cigarette consumption in Turkey: Evidence from the Global Adult Tobacco Survey. Health Policy, 114(2-3), 207-214.

Köse, T. (2019). Smoking quit attempts in Turkey: An analysis of gender differences. Addicta: The Turkish Journal on Addictions, 6(4), 130-146.http://dx.doi. org/10.5152/addicta.2020.19108

Leuenberger, P., Schwartz, J., Ackermann-Liebrich, U., Blaser, K., Bolognini, G., Bongard, J. P., Brandli, O., Braun, P., Bron, C., \& Brutsche, M. (1994). Passive smoking exposure in adults and chronic respiratory symptoms (SAPALDIA Study). Swiss Study on Air Pollution and Lung Diseases in Adults, SAPALDIA Team. American journal of respiratory and critical care medicine, 150 (5 Pt 1), 1222-1228. https:// doi.org/10.1164/airccm.150.5.7952544

Levy, D. T., Chaloupka, F., \& Gitchell, J. (2004). The effects of tobacco control policies on smoking rates: a tobacco control scorecard. Journal of Public Health Management and Practice, 10(4), 338-353.

Liang, L., \& Chaloupka, F. J. (2002). Differential effects of cigarette price on youth smoking intensity. Nicotine \& Tobacco Research, 4(1), 109-114.

McCormick, M. C., Shapiro, S., \& Starfield, B. (1984). High-risk young mothers: infant mortality and morbidity in four areas in the United States, 1973-1978. American journal of public health, 74(1), 18-23. https://doi.org/10.2105/ajph.74.1.18

Öberg, M., Jaakkola, M. S., Woodward, A., Peruga, A., \& Prüss-Ustün, A. (2011). Worldwide burden of disease from exposure to second-hand smoke: a retrospective analysis of data from 192 countries. The lancet, 377(9760), 139-146.

Official Journal. (1996, November 26). The Law No. 4207 "The Prevention of Harmful Effects of Tobacco Products". https://www.resmigazete.gov.tr/arsiv/22829.pdf

Rachiotis, G., Siziya, S., Muula, A. S., Rudatsikira, E., Papastergiou, P., \& Hadjichristodoulou, C. (2010). Determinants of exposure to environmental tobacco smoke (ETS) among non smoking adolescents (aged 11-17 years old) in Greece: results from 
the 2004-2005 GYTS Study. International journal of environmental research and public health, 7(1), 284-290.

Republic of Turkey Ministry of Health(2014), Global Adult Tobacco Survey Turkey 2012, Publication No 948, Ankara

Shapiro, S., McCormick, M. C., Starfield, B. H., Krischer, J. P., \& Bross, D. (1980). Relevance of correlates of infant deaths for significant morbidity at 1 year of age. American journal of obstetrics and gynecology, 136(3), 363-373. https://doi. org/10.1016/0002-9378(80)90863-7

Singh, A., \& Ladusingh, L. (2014). Prevalence and determinants of tobacco use in India: evidence from recent Global Adult Tobacco Survey data. PloS one, 9(12).

Spitzer, W. O., Lawrence, V., Dales, R., Hill, G., Archer, M. C., Clark, P., Abenhaim, L., Hardy, J., Sampalis, J., \& Pinfold, S. P. (1990). Links between passive smoking and disease: a best-evidence synthesis. A report of the Working Group on Passive Smoking. Clinical and investigative medicine. Medecine clinique ex experimentale, 13(1), 17-46.

Steenland K. Passive Smoking and the Risk of Heart Disease. JAMA. 1992;267(1):9499. doi:10.1001/jama.1992.03480010102033

Tauras, J. A. (2006). Smoke-free air laws, cigarette prices, and adult cigarette demand. Economic Inquiry, 44(2), 333-342.

Tepehan Eraslan, S., Demirkıran, S., \& Duran, S. (2019). Factors affecting cigarette consumption: The case of the Keșan and İpsala districts of Edirne. Addicta: The Turkish Journal on Addictions, 6(4), 87-98. http://dx.doi.org/10.5152/addicta.2020.19070

Trédaniel, J., Boffetta, P., Saracci, R., \& Hirsch, A. (1993). Environmental tobacco smoke and the risk of cancer in adults. European journal of cancer (Oxford, England : 1990), 29A(14), 2058-2068. https://doi.org/10.1016/0959-8049(93)90471-q

Trédaniel, J., Boffetta, P., Saracci, R., \& Hirsch, A. (1994). Exposure to environmental tobacco smoke and adult non-neoplastic respiratory diseases. The European respiratory journal, 7(1), 173-185. https://doi.org/10.1183/09031936.94.07010173

Warren, C. W., Erguder, T., Lee, J., Lea, V., Sauer, A. G., Jones, N. R., \& Bilir, N. (2012). Effect of policy changes on cigarette sales: the case of Turkey. The European Journal of Public Health, 22(5), 712-716.

Wells A. J. (1991). Breast cancer, cigarette smoking, and passive smoking. American journal of epidemiology, 133(2), 208-210. https://doi.org/10.1093/oxfordjournals.aje.a115859

Wilson, N., \& Thomson, G. (2002). Still dying from second-hand smoke at work: a brief review of the evidence for smoke-free workplaces in New Zealand. The New Zealand medical journal, 115(1165), U240.

World Health Organization. Regional Office for Europe. (2000). Air quality guidelines for Europe, 2nd ed. Copenhagen : WHO Regional Office for Europe. https://apps. who.int/iris/handle/10665/107335 
World Helath Organization. (2020, May 27). Tobacco. https://www.who.int/news-room/fact-sheets/detail/tobacco

Yanbaeva, D. G., Dentener, M. A., Creutzberg, E. C., Wesseling, G., \& Wouters, E. F. (2007). Systemic effects of smoking. Chest, 131(5), 1557-1566.

Yazıcı, H., Camadan, F., \& Kahveci, G. (2017). Adapting the Smoking Expectancy Scale for Adolescents (SESA) to Turkish culture. Addicta: The Turkish Journal on Addictions, 4, 207-220.http://dx.doi.org/10.15805/addicta.2017.4.2.0009

Ylldı, F. (2020). Determinants of cigarette consumption in Turkey: An ARDL bounds testing approach. Addicta: The Turkish Journal on Addictions, Online first publication.http://dx.doi.org/10.5152/addicta.2020.19045. 
